\title{
Digital Regulation of the Agro-industrial Complex for Achieving Leadership
}

\author{
Mikhail Chernyakov \\ Faculty of Business \\ Novosibirsk State Technical University \\ Karl Marx Ave. 20, 630073 Novosibirsk \\ Russian Federation \\ e-mail:mkacadem@mail.ru \\ Maria Chernyakova \\ Faculty of Public Administration \\ Siberian Institute of Management \\ Nizhegorodskaya Str. 20, 630102 Novosibirsk \\ Russian Federation \\ e-mail: mariamix@mail.ru
}

\begin{abstract}
In terms of gross agricultural output, the Russian agribusiness is one of the leaders in the world. However, the insufficient state support provided to livestock industries as the raw material basis of domestic food and the slight expansion of the country's export potential characterize the level of production efficiency, technical and technological equipment of most organizations of the agribusiness as low. Urgent measures to strengthen the government support and stimulate the agricultural sector, and above all through effective transformation into a digital economy, are needed to eliminate this problem. Morphological analysis was chosen as the main research method, which represents an effective methodological approach - a way of seeing and a generalized attitude to reality. A morphological rectangular parallelepiped was constructed, which made it possible to single out the most significant for the purpose of analyzing the parameter of regulation of the agribusiness digitalization ones, the variability of which is due to the elements of the essential model of the digitalization system, the structure of subcomplexes and the dynamics of the organizations' development. The results of a priori analysis in the form of bar charts were implemented in a morphological rectangular parallelepiped. They showed that the highest priority in the study should be given to the reasons for the need to regulate the agricultural sector of the agribusiness. According to the results of the morphological analysis, it is possible to form areas for future research. The aim of further research should be to improve theoretical principles and develop practically important recommendations for predicting the effectiveness of regulating the parameters of the agribusiness in the context of transformation into a digital economy.
\end{abstract}

\section{Introduction}

In terms of gross agricultural production, the Russian agribusiness is one of the leaders in the world (Scientific and technical development forecast 2017). Despite the rather high level of food security achieved in the Russian Federation which in most positions exceeds the targets of the Doctrine of Food Security (2017) of the Russian Federation, the dairy industry is an unfortunate exception.

The insufficient state support provided to the livestock industries as the raw material basis of domestic food and the slight expansion of the country's export potential characterize the level of production efficiency, technical and technological equipment of most organizations of the agribusiness as low. Urgent measures to strengthen the government support and stimulate the agricultural sector, and above all through effective transformation into a digital economy, are needed to eliminate this problem. To solve the stated problem, a morphological analysis was chosen as the main research method, which is an effective methodological approach - a way of seeing and a general attitude to reality.

\section{Research methodology}

Morphological analysis was chosen as the main research method, which is an effective methodological approach - a way of seeing and a generalized attitude to reality. Zwicky (1969) suggested that in the final and true image of the world, everything is related to everything, and nothing can be a priori dismissed as Zwicky suggested insignificant'. 


\section{Research results}

The concept of 'digital economy' does not yet have an unambiguous, clear terminological concept due to the large number of its diverse interpretations. The following essential definition was chosen as the base in the research: "The digital economy is an environment that includes a combination of digital infrastructure and innovative diversified information and communication technologies for doing business' (Chernyakov 2019), which has been effectively used in studies on the regulation of digitalization of agricultural organizations. The term 'innovation diversification' (Chernyakov 2016) has been used by the scientific community since 2016 and characterizes the penetration of innovations into new areas.

Taking into account the transition of the agribusiness to the digital economy, research should rely on the following definition: 'state regulation in agriculture is the real-time economic impact of authorities on the agricultural infrastructure complex using digital support for the production, processing, sale of agricultural products, raw materials and food' (Chernyakov 2019).

Based on various sources of information, a system for the development of organizations of the agribusiness was proposed (Fig. 1), which is a closed system consisting of four basic elements: causes, aims, functions and principles of state regulation of the agribusiness. All of the listed components of the system elements are exemplary, not constant, and changing their components requires adjustment of other elements (one or more). Consequently, the system is dynamically changing, and the task of regulation is to determine the vector of these changes.

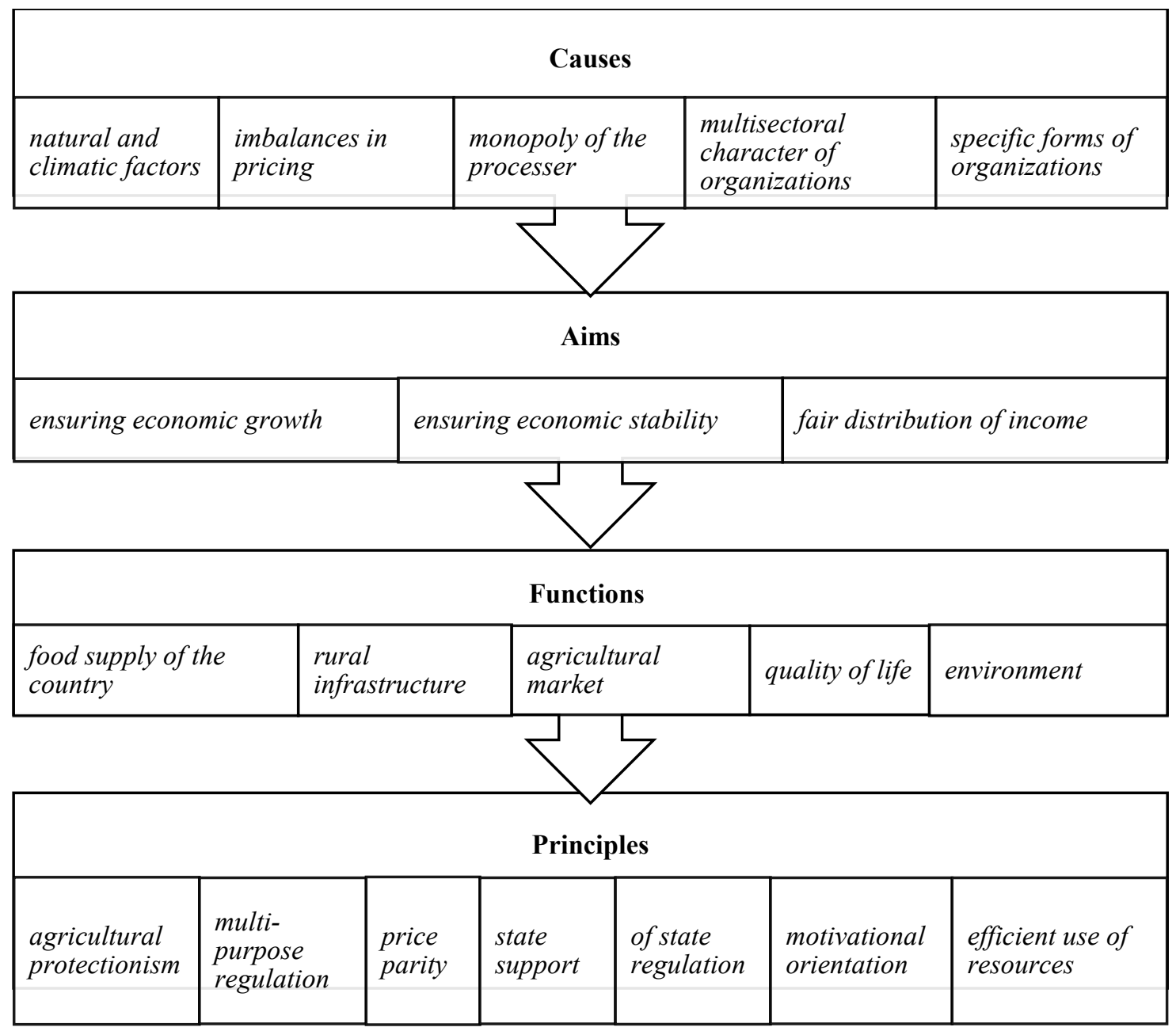

Fig.1. Development system of the agribusiness Source: Gritsenko (2019)

The structure of the agribusiness in the Russian Federation can be represented as a system consisting of three interconnected subcomplexes (Fig. 2), combining three areas of activity: agricultural (crop production, animal husbandry, etc.), industrial (processing of agricultural products) and service (implementation of 
agricultural products and products of its processing). The essential structure of the functioning system is a chain, the first link of which is the agricultural sector, the second - industrial and closing - services.

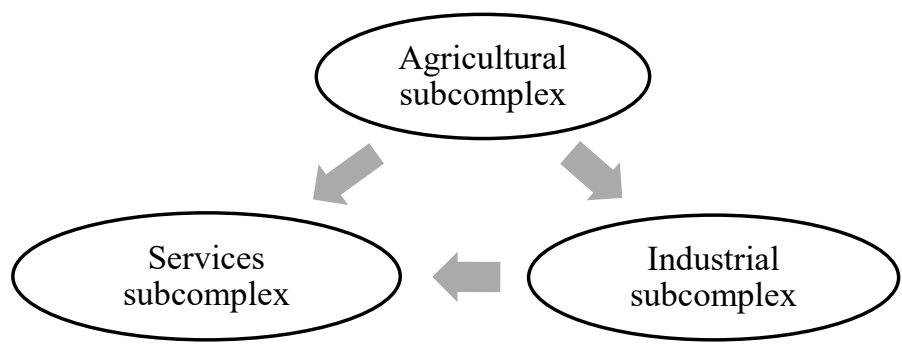

Fig.2. The essential structure of the agribusiness Source: Gritsenko (2019)

Now there is high competition in the market of agricultural products. This creates high requirements to the product quality. And, unfortunately, the main turnover belongs to large companies. They do not allow small and medium-sized enterprises to enter the market of agricultural products and win more consumers. Therefore, according to novice entrepreneurs, the agribusiness is not a promising area of business development. To eliminate this problem, measures of regulatory impact are needed, the effectiveness of which can be significantly improved by accelerating the transformation of the totality of all subcomplexes of the agribusiness into a digital economy through information and computer technologies. The impact of digital technologies on changing social and economic systems (Fig. 2) is noticeable, however, most of the issues remain poorly studied (Chernyakova 2018). For a detailed study of this influence, it is proposed to study the essential structure of the transformation model, the scheme of which is shown in Fig. 3.

It is proposed to consider the essential model of the digitalization system of state regulation of the agribusiness as a closed system consisting of three elements: state regulation, digitalization and parameters of the industry objects. The 'State regulation' block through regulatory levers exerts disturbing effects on the 'Digitalization' block. A reaction to the disturbing effect is the development of information and computer technologies that are transferred for use directly in the organization of the agribusiness. The results of the application of information and computer technologies are analyzed and the effect (positive or negative) in the form of feedback is transmitted to the regulatory authorities. The received response is analyzed, the regulatory actions are adjusted, and the system cycle is repeated.

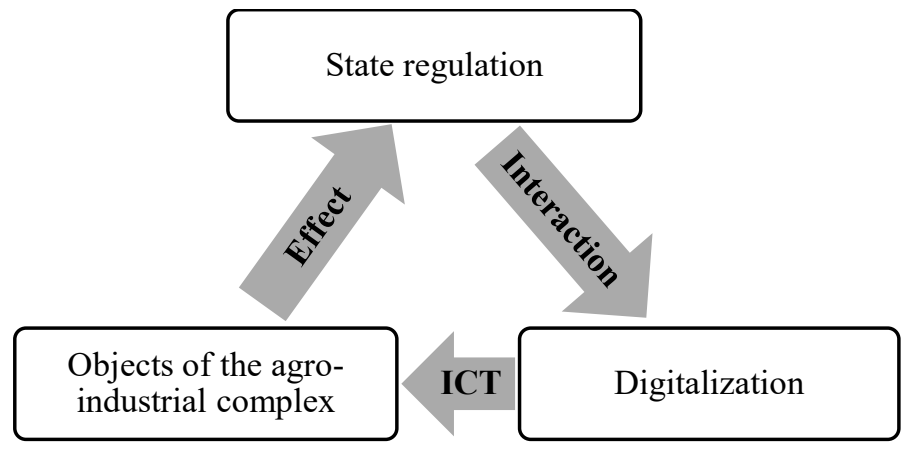

Fig.3. The essential model of the digitalization system of state regulation of the agribusiness Source: Gritsenko (2019)

Morphological analysis (MA) (Zwicky 1969) or general morphological analysis (GMA) (Ritchey 2013 ) is a method for creatively solving multidimensional, complex problems by systematically structuring them and exploring the space of all possible solutions, as well as an effective tool for creating creative ideas and development of new products, technologies and services.

The method is based on the analysis of system attributes and parameters, the generation of alternative options for their presentation, as well as the creation and selection of their new combinations.

Morphological analysis requires the determination of all possible elements on which the solution of the problem may depend, listing the possible values of these elements, and then it is necessary to generate alternative solutions by enumerating all possible combinations of these values.

Morphological analysis of the essential model of the system of digitalization of state regulation of the agribusiness (Fig. 3) demonstrates that each of its elements can cover all areas of the essential structure of 
the agribusiness (Fig. 2), creating a decision field (three by three) out of 9 possible combinations. In addition, each of these combinations includes all elements of the agribusiness development system (Fig. 1), creating a volume of 36 possible combinations that can be depicted as a rectangular parallelepiped (Fig. 4).

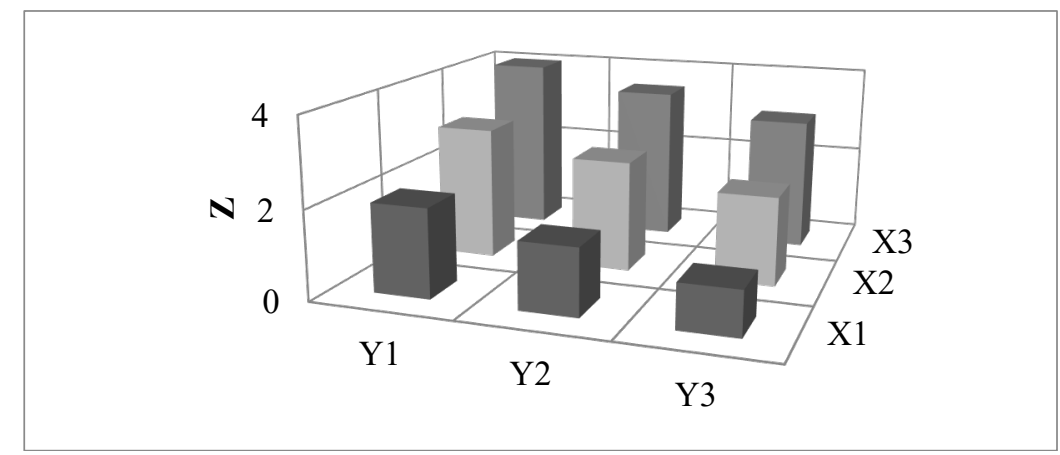

Fig.4. Morphological cuboid

Source: Own results

Figure 4 shows a morphological rectangular parallelepiped that allows one to single out the most important for the purpose of analysis of the digitalization regulation parameter of the agribusiness (Table 1), the variability of which is due to the elements of the essential model of the digitalization system (X), the structure of subcomplexes (Y) and the dynamics of the development of organizations $(\mathrm{Z})$.

Table 1. Structure elements

\begin{tabular}{|l|l|l|}
\hline \multicolumn{1}{|c|}{ Digitalization systems: } & \multicolumn{1}{c|}{ Subcomplexes } & \multicolumn{1}{c|}{ Organizational development } \\
\hline X1 - Regulation & Y1 - Agricultural & Z1 - Causes \\
\hline X2 - Digitalization & Y2 - Industrial & Z2 - Aims \\
\hline X3 - Objects & Y3 - Service & Z3 - Functions \\
\hline & & Z4 - Principles \\
\hline
\end{tabular}

Source: Own results

The morphological cuboid (Fig. 4) is a multidimensional matrix of the decision space, each axis of which acts as a subsystem and is associated with other subsystems, in some cases hierarchically (development system of organizations). The matrix allows you to determine possible configurations and limitations of consistency, from the reasons for the need to regulate the agricultural sector of the agribusiness (X1-Y1-Z1) to the principles of facilities development for the service sector of the agribusiness (X4-Y4-Z4). This allows one to evaluate and choose the most productive ideas and solutions. All possible elements are determined on which the solution to the problems of transforming the agribusiness into the digital economy may be determined, possible values of the necessary information and computer technologies are listed, and then alternative solutions are generated by enumerating all possible scenarios to achieve the target values of the parameters of the objects of the agribusiness due to directed regulatory influences.

For clarity, the volumetric matrix of the agribusiness was transformed into three flats by fields of activity, which are presented in three Tables 2-4. It is assumed that the mutual combination of these factors determines the content of digital regulation of the agribusiness. The positive result of applying the morphological method directly depends on the subjective processes of evaluating and selecting key parameters and the variety of their alternatives and, ultimately, the most useful combination of them. For this, it is necessary to evaluate each combination of the matrix.

\section{Discussion of the study results}

To evaluate each combination of the matrix, the a priori ranking method was applied, which should be used to process the data obtained as a result of studies analysis published in open sources. Such an examination makes it possible to more correctly set the aim and objectives of the upcoming studies, formulate directions and preliminary hypotheses, evaluate the influence of regulation indicators on the parameters of the agribusiness and identify factors for subsequent studies, excluding the insignificant ones from further consideration. 
Table 2. The matrix regulating the transformation of the agricultural sector into a digital economy for the agricultural sector

\begin{tabular}{|l|l|l|l|}
\hline Y1 - Agricultural & \multicolumn{1}{|c|}{ X1 - Regulation } & \multicolumn{1}{|c|}{ X2 - Digitalization } & \multicolumn{1}{c|}{ X3-Object } \\
\hline Z1 - Causes & $\begin{array}{l}\text { Significant impact of natural } \\
\text { and climatic factors. } \\
\text { Lack of funding. }\end{array}$ & $\begin{array}{l}\text { Direct regulatory } \\
\text { impact on the } \\
\text { parameters of the } \\
\text { agricultural sector. }\end{array}$ & $\begin{array}{l}\text { Need to develop agricultural } \\
\text { organizations to ensure food } \\
\text { security. }\end{array}$ \\
\hline Z2- Aims & $\begin{array}{l}\text { Fair distribution of income } \\
\text { among members of the society, } \\
\text { providing equal chances in the } \\
\text { market, fair market competition, } \\
\text { etc. }\end{array}$ & $\begin{array}{l}\text { Development of } \\
\text { information and } \\
\text { computer technologies } \\
\text { for targeted regulation } \\
\text { of the parameters of the } \\
\text { agricultural sector. }\end{array}$ & $\begin{array}{l}\text { Implementation of information } \\
\text { and computer technologies } \\
\text { regulating the parameters of } \\
\text { agricultural organizations. }\end{array}$ \\
\hline Z3- Functions & $\begin{array}{l}\text { Stimulating balanced economic } \\
\text { growth through digital } \\
\text { technology. } \\
\text { Orientation of legislation on } \\
\text { improving the quality of life of } \\
\text { the rural population. } \\
\text { Environmental protection and } \\
\text { natural resources management. }\end{array}$ & $\begin{array}{l}\text { Analysis of the state of } \\
\text { the agricultural sector. } \\
\text { Development of } \\
\text { software. } \\
\text { Algorithmizing. } \\
\text { Programming. } \\
\text { Adaptating. }\end{array}$ & $\begin{array}{l}\text { New business processes in } \\
\text { agricultural organizations } \\
\text { (smart farms, etc.), } \\
\text { organizational structures, } \\
\text { regulations, rules, new } \\
\text { responsibility for data, new role } \\
\text { models. }\end{array}$ \\
\hline Z4- Principles & $\begin{array}{l}\text { Rational agricultural } \\
\text { protectionism. } \\
\text { Support, motivational } \\
\text { orientation, most efficient use } \\
\text { of resources. }\end{array}$ & $\begin{array}{l}\text { Changing the form of } \\
\text { doing business in rural } \\
\text { areas in a digital reality } \\
\text { based on data. }\end{array}$ & $\begin{array}{l}\text { Transition to agricultural } \\
\text { organizations conducting } \\
\text { business in digital reality based } \\
\text { on data. }\end{array}$ \\
\hline
\end{tabular}

Source: Own results

The ranking of the combinations presented in the matrix was based on an a priori analysis of Russian open sources (Chernyakov 2019; Ivanova 2018; Kuchumov 2019; Pavlov 2019; Syaglova 2018) and overseas (Carolan 2017; Ingrand 2018; Pandithurai 2017) researchers on the arithmetic mean of the sum of places. The arithmetic mean value criterion was justified by the fact that not all combinations presented in the matrix were present in the analyzed sources.

Table 3. The matrix of transformation of the agribusiness into a digital economy for the industrial sector

\begin{tabular}{|c|c|c|c|}
\hline Y2 - Industrial & X1-Regulation & X2 - Digitalization & X3 - Object \\
\hline Z1 - Causes & $\begin{array}{l}\text { Dependence of the } \\
\text { producer on the local } \\
\text { monopoly of the } \\
\text { agricultural processor. }\end{array}$ & $\begin{array}{l}\text { Indirect regulatory } \\
\text { impact on industrial } \\
\text { sector parameters. }\end{array}$ & $\begin{array}{l}\text { Need for the development of } \\
\text { processing enterprises (smart } \\
\text { factories, workshops, sites, } \\
\text { etc.) in a highly competitive } \\
\text { environment. }\end{array}$ \\
\hline Z2-Aims & $\begin{array}{l}\text { Ensuring } \\
\text { growth, which involves } \\
\text { the progress of the } \\
\text { economy of a state or } \\
\text { region, which is expressed } \\
\text { in changes in the general } \\
\text { situation of the economy. }\end{array}$ & $\begin{array}{l}\text { Development of } \\
\text { information and } \\
\text { computer technologies } \\
\text { for targeted regulation } \\
\text { of of the industrial sector } \\
\text { parameters. }\end{array}$ & $\begin{array}{l}\text { Implementing the information } \\
\text { and computer technologies. }\end{array}$ \\
\hline Z3-Functions & $\begin{array}{l}\text { Creating market } \\
\text { production infrastructure } \\
\text { in rural areas. }\end{array}$ & $\begin{array}{l}\text { Analysis of the state of } \\
\text { the industrial sector. } \\
\text { Development } \\
\text { software. } \\
\text { Algorithmizing. } \\
\text { Programming. } \\
\text { Adaptating. }\end{array}$ & $\begin{array}{l}\text { New business processes, } \\
\text { organizational structures, } \\
\text { regulations, rules, new } \\
\text { responsibility for data, new role } \\
\text { models. }\end{array}$ \\
\hline Z4 - Principles & $\begin{array}{l}\text { The combination of } \\
\text { economic and social goals. } \\
\text { Program-targeted } \\
\text { regulation. }\end{array}$ & $\begin{array}{l}\text { Changing the business } \\
\text { form in processing } \\
\text { enterprises in digital } \\
\text { reality based on data. }\end{array}$ & $\begin{array}{l}\text { Transition to processing } \\
\text { enterprises conducting business } \\
\text { in digital reality based on data. }\end{array}$ \\
\hline
\end{tabular}

Source: Own results 
Table 4. The matrix regulating the transformation of the agribusiness into a digital economy for the service sector

\begin{tabular}{|l|l|l|l|}
\hline \multicolumn{1}{|c|}{ Y3 - Service } & \multicolumn{1}{|c|}{ X1 - Regulation } & \multicolumn{1}{c|}{ X2 - Digitalization } & \multicolumn{1}{c|}{ X3 - Object } \\
\hline Z1 - Causes & $\begin{array}{l}\text { Imbalances in pricing } \\
\text { between agricultural and } \\
\text { industrial products. } \\
\text { The multisectoral nature } \\
\text { of organizations. }\end{array}$ & $\begin{array}{l}\text { Secondary indirect } \\
\text { regulatory impact on } \\
\text { service sector } \\
\text { parameters. }\end{array}$ & $\begin{array}{l}\text { Need to develop trade } \\
\text { enterprises (vending machines } \\
\text { for food products, etc.) in a } \\
\text { competitive environment. }\end{array}$ \\
\hline Z2- Aims & $\begin{array}{l}\text { Ensuring economic } \\
\text { stability, which involves } \\
\text { maintaining the stability } \\
\text { of commodity prices, } \\
\text { preventing and containing } \\
\text { hyperinflation, etc. }\end{array}$ & $\begin{array}{l}\text { Development of } \\
\text { information and } \\
\text { computer technologies } \\
\text { for targeted regulation } \\
\text { of the parameters of the } \\
\text { service sector. }\end{array}$ & $\begin{array}{l}\text { Implementation of information } \\
\text { and computer technologies } \\
\text { regulating the system of trade } \\
\text { organizations. }\end{array}$ \\
\hline Z3- Functions & $\begin{array}{l}\text { Creating a sustainable } \\
\text { food supply system of the } \\
\text { country. } \\
\text { Formation of an } \\
\text { efficiently functioning } \\
\text { market for agricultural } \\
\text { products, raw materials } \\
\text { and food. }\end{array}$ & $\begin{array}{l}\text { Analysis of the state of } \\
\text { the service sector. } \\
\text { Development of } \\
\text { software. } \\
\text { Algorithmizing. } \\
\text { Programming. } \\
\text { Adaptating. }\end{array}$ & $\begin{array}{l}\text { New business processes, } \\
\text { organizational structures, } \\
\text { regulations, rules, new } \\
\text { responsibility for data, new role } \\
\text { models. }\end{array}$ \\
\hline Z4 - Principles & $\begin{array}{l}\text { Establishment and } \\
\text { maintenance of parity of } \\
\text { prices and incomes in } \\
\text { agriculture and other } \\
\text { sectors of the economy. }\end{array}$ & $\begin{array}{l}\text { Changing the business } \\
\text { form of trade } \\
\text { organizations in digital } \\
\text { reality based on data. }\end{array}$ & $\begin{array}{l}\text { Transition to trade } \\
\text { organizations conducting } \\
\text { business in digital reality based } \\
\text { on data. }\end{array}$ \\
\hline
\end{tabular}

Source: Own results

The results of a priori analysis in the form of bar charts were implemented in a morphological rectangular parallelepiped (Fig. 4). From Figure 4 it follows that the highest priority in the study should be given to the reasons for the need to regulate the agricultural sector of the agribusiness (X1-Y1-Z1). This puts forward the task of analyzing the state of the agricultural sector of the agribusiness and regulating its development.

The priority value of identifying the causes is explained by the fact that they are necessary for setting aims and objectives. An incorrectly set aim will lead to irreparable results in the formation of functions and principles, as well as to an incorrect calculation of the necessary volumes of state support. The priority value of the agricultural subcomplex is determined by the fact that it produces the initial products for the industrial and service sectors. The priority value of regulation characterizes it as one of the necessary sources of investment in the agricultural sector.

\section{Conclusions}

According to the results of morphological analysis, it is possible to form areas of future research. The aim of further research should be to improve theoretical principles and develop practically important recommendations for predicting the effectiveness of regulating the parameters of the agribusiness in the context of transformation into a digital economy. To achieve this goal, the following tasks must be solved

- The theoretical foundations of increasing the efficiency of regulation of the parameters of the agribusiness in the conditions of transformation into the digital economy are clarified

- An algorithm of the mechanism for regulating the agribusiness is developed on the basis of a synergistic approach

- Digital technology for predicting the results of regulation of the parameters of the agribusiness is proposed

- Scenarios for forecasting the results of state regulation of the agribusiness to achieve the set aims are compiled. 


\section{References}

Carolan M (2017) Agro-Digital Governance and Life Itself: Food Politics at the Intersection of Code and Affect. Sociologia Ruralis 57 (1):816-835. doi: 10.1111/soru.12153.

Chernyakov MK, Chernyakova MM, Ratmanova YA, Harutyunyan NV (2016) Innodiversifikaciya. Konkurentnosposobnost v globalnom mire: ekonomika, nauka, tekhnologii 6:283-187.

Chernyakov MK, Chernyakova MM, Regulirovaniye cifrovoy ekonomiky selskogo hozyaystva: monografiya, $1^{\text {st }}$ edn. (NSTU: Novosibirsk, Russia, 2019), 262 p.

Chernyakova MM (2018) Socio-ekonomicheskiye faktory cifrovogo razvitiya. Nauka Krasnoyarska 7(32):116-122.

Gritsenko GM, Chernyakova MM, Ermakov AO (2019) Suschnostnaya model sistemy gosudarstvennogo regulirovaniya cifrovizacii molochnoy otrasli. Nauka Krasnoyarska 8(2-3): 24-31.

Ingrand S (2018) Opinion paper: Monitoring te salutant. Combining digital sciences and agro-ecology to design multi-performant livestock farming systems. Nimal 12(1):2-3. doi: 10.1017/s1751731117001999

Ivanova EV, Merkulova EY (2018) Qualitative changes of the state regulation of reproduction processes in agriculture based on digital technologies. Quality-access to success 19 (2): 130-134.

Kuchumov AV (2019) Digital technologies as a factor in the innovative development of the agribusiness to ensure the food security of the country. 1st International Scientific Conference on Modern Management Trends and the Digital Economy - From Regional Development to Global Economic Growth (MTDE 2019), Book Series: AEBMR-Advances in Economics Business and Management Research 81:28-35. doi:10.2991/mtde19.2019 .6

Pandithurai O, Aishwarya S, Aparna B, Kavitha K (2017) Agro-tech: a digital model for monitoring soil and crops using internet of things (IoT). 3rd IEEE International Conference on Science Technology Engineering \& Management (ICONSTEM), pp. 342-346. doi: 10.1109/iconstem.2017.8261306

Pavlov AYu, Batova VN, Popov VV (2019) Introduction of digital technologies in the agribusiness as a tool for ensuring sustainable development of rural areas. 1st International Scientific Conference on Modern Management Trends and the Digital Economy - From Regional Development to Global Economic Growth (MTDE 2019). Book Series: AEBMR-Advances in Economics Business and Management Research 81: 340 344. doi: $10.2991 / \mathrm{mtde}-19.2019 .65$

Ritchey T (2013) General Morphological Analysis: A general method for non-quantified modeling. Swedish Scientific and technical development forecast of the agricultural sector of the Russian Federation for the period up to year $2030 \quad$ (2017) https://issek.hse.ru/data/2017/02/06/1167349282/Прогноз\%20научнотехнической\%20сферы.pdf. Accessed 15 Oct 2019.

Syaglova Yu (2018) Features of application of digital technologies in retail trade in foodstuff. Economy, labor, management in agriculture 8: 131-138. doi: 10.33938/188-131

The Doctrine of Food Security of the Russian Federation for the period up to year 2020 (2017) http://kremlin.ru/events/president/news/6752. Accessed 15 Oct 2019

Zwicky F (1969) Discovery, Invention, Research. Through the Morphological Approach 1:276. doi: 10.1126/science.163.3873.1317 